\title{
Introduction to the Historical Past: Informal Educational Media Practices in Modern Russia
}

\section{Murzina Irina}

Institute for Educational Strategies, Ekaterinburg, Russia

ekb-ural@yandex.ru

\begin{abstract}
Relevance of research. The article discusses the situation in the Russian education system in 2020, during the COVID-19 pandemic followed by a restraint mode. This is the time of active implementation of digital technologies in education and increased importance of media. The relevance of the article is associated with the need to structure media practices, that proved a good potential during that period, and a theoretical analysis of their place in the education system. The author identifies for the analysis aspects related to the problem of introducing children and youth to the historical traditions in the new social and cultural context.

Research objective - To summarise a number of media practices updated during the pandemic and associated with introducing pupils to the historical past.

Research methodology and methods. The research is based on an interdisciplinary methodology that allows integrating the achievements of various social sciences and humanities. The cluster analysis and content analysis of electronic information, outreach and educational resources were used as private methods. To identify promising educational trends, the materials of informal expert interviews were analysed.

Research novelty. The article presents a conceptual and categorical grid 'media environment - media activity - media practice, which is used to describe informal educational media practices. The author analyses three groups of media activities: 1) focused on expanding the educational field for schoolchildren (case The 75th Anniversary of the Great Victory), 2) offering new forms of family leisure (case 'Then an inventor appeared...') and 3) creating new professional activity opportunities for teachers (case 'Urals during the Great Patriotic War': scientific and methodological work in the context of digitalisation').

As a result of the research, it is concluded that the described informal educational media practices, despite their specific content (Russian patriotic discourse), can be considered as versatile and promising: the use of new teaching
\end{abstract}


and personal development formats can expand the range of instructional tools in both formal and non-formal education.

Keywords: educational media practices, e-learning, media environment, non-formal education, Russian patriotic discourse

\section{Introduction}

The purpose of the article is to summarise a number of media practices that were updated during the pandemic and associated with introducing pupils to the historical past. The paper examines the features of media practitioners in informal education.

The situation in which the world finds itself in 2020 - the COVID-19 pandemic and the ensuing restraint mode - intensified the transition to and rapid development of the virtual space. The transition to the online mode turned out to be unexpected for not only education but it is the education and personal development process that can be considered an indicator reflecting the nature of social transformations. If the discussions of the education digitalisation features that have taken place over the past years [Valadez, Uvarov, Van, Kan et al., 2019; Difficulties and Prospects of Digital Transformation of Education, 2019; Elliott, 2017; Devine, 2014; Durán, 2007; Kerr, 2005; Negroponte, 1995], the prospects that open up in connection with the technological revolution [Schwab, 2016; New Technological Revolution, 2017], the emergence of new educational practices were rather the nature of intellectual reflections, then in 2020 all the fears and positive achievements of the inclusion of information and communication achievements in education have become the facts of life. Digital technologies were actively introduced into education along with reflection aimed at comprehending personal instructive experience and determining vectors for the system's development as a whole.

Critical assessments of 'violent digitalisation' that have reigned in the first months of the pandemic, as teachers, students and their parents mastered new technologies, began to give way to more balanced judgments by mainstreaming the role and place of media practitioners in education [Goldman, 2019; Chelysheva, Shapovalova, Muryukina, 2019; Kornienko, Potapov, Petrova, 2020].

Conventionally, issues of the role of media in education have been discussed in the context of including audiovisual materials as supplementary materials in training courses, fostering critical thinking, and creative projects 
shaped in the electronic environment [Fedorov, 2015]. Today, the importance of media has increased many times by creating a new reality - the interpenetration and mutual conditioning of the real and the virtual. In this regard, it is necessary to systematise media practitioners who have shown promise during the pandemic, and a theoretical analysis of their place in the Russian education system.

The aspect, that we have identified for analysis is related to introducing children and youth to the historical traditions in the new social and cultural conditions. Essentially, the topic of introducing pupils to history and comprehending the values of the past for education has repeatedly become the target of research including our works [Murzina, 2019]. The research into the historical past is an important factor for the social and personal development (the personal and collective identity generation); it determines the scope of cognitive interests, acts as an important condition for the intellectual, artistic and aesthetic formation of a person. The cultural values are learnt through introducing an individual to culture, assimilating existing habits, norms and patterns of behaviour (inculturation) and assimilating a certain system of knowledge, norms and values that make it possible him/her to function as a full member of society (social engagement). The mechanism for assimilating values is through acquaintance with samples of culture, introduction to values, i. e. the acceptance and interiorisation of values and models.

Today, the media environment is viewed as a social and cultural space shaped primarily by electronic means and providing indirect communication between people. Its importance increases as individuals and social groups are included in its orbit. The explosive growth of media practitioners during the pandemic partly created and partly updated the previously existing new opportunities for introducing learners to the historical past.

\section{Research methodology and methods}

The research is based on an interdisciplinary methodology that allows integrating the achievements of various social sciences and humanities. The methods of cluster analysis and content analysis of electronic awareness-raising, outreach and educational resources were used as private methods. To identify promising educational trends, we turned to the materials of informal expert interviews with teachers in the city of Ekaterinburg and the Sverdlovsk region (in total, the number of interviewees was more than 200 people) conducted by us in 2010-2019 and online surveys conducted 
in April-September 2020 (expert interviews were conducted with 50 teachers of secondary schools and university teachers in Ekaterinburg).

\section{Results and discussions}

The contemporary education system unites into a complex unity formal (implemented in educational institutions according to approved state programmes and with the receipt of academic certificates at the end), non-formal (implemented in the additional education, has the qualities of institutionalisation, being purposeful and planned by a person or organisation of activities that provide educational services including various courses, training and/ or short educational programmes [Chekalova, Roitblat, Surtaeva, 2012]); informal (non-institutional forms of education implemented through communication, reading, visiting cultural institutions, travel, mass media etc.) components. Both non-formal and informal education fosters lifelong learning ideas and ensures that the need for customisation of the learning process itself is met. It remains an urgent task to find ways to integrate them.

In the modern cultural studies and pedagogics, the practice of using media is considered in the context of mastering the meanings and values of culture, mediated by a set of technological means and communication methods that serve to transmit information messages in the form of text, music or images. Modern man lives in a constantly changing social and cultural context, a media environment in which the real and the virtual mutually condition each other, new technologies determine human existence; it is an imperative of our time to handle information flows.

Media practices are the use of information and communication tools for the creation and consumption of certain content as well as for the implementation of social connections and interactions [Kolomiets, 2010, 61]. Media practices are regarded as the areas of informal education.

Media activity is the ability of a person to quickly receive, systematise, perceive and evaluate information from various media channels. It manifests itself in the forms of behaviour, lifestyle and styles of thinking implemented in the information space, or in the media environment [Simbirtseva, 2016].

Media activities are multidirectional forms of activity of an individual or a group of people in the information space including the production and consumption of content. We consider media activities as forms of activity in the context of the informal education functioning. 
The functioning of the media environment creates certain complications for education. First of all, they are related to the transformations that the traditional values of Russian society undergo, such as Fatherland, family, the world in which a person lives, the very existence of a person. Personal identity becomes fluid; it changes under the influence of circumstances, communication situations and group relationships. The meanings of the concepts 'commonwealth', 'community', 'partnership', that are traditionally significant for the development of personality and society, are changing; they acquire a new meaning in the virtual world: groups exist in social networks, friends exist in the news feed; the warmth of human connections is being lost, instead of which subscribers and commentators of personal pages and Internet channels become significant 'others'. There is an illusion that the multiplicity and mosaicism of points of view on the world does not require certainty in value orientations and personal choice. Today, it is urgent to search for new forms and means that provide and shape a stable value-based and standard-based personality type. In providing conditions for shaping the value orientations of young people, the educational nature of the media environment is manifested. It is implemented through the proposed media activity. It was them who became significant in the context of the COVID-19 pandemic and the unexpected lockdown.

In the context of the current events, the topic of introducing pupils to the historical past and raising awareness of its significance acquires additional meaning. We will consider a number of cases illustrating the media practices of informal education on the Internet. Due to the limited space of the article, we will not consider all possible options for introducing pupils to the historical and cultural heritage that exist in the media environment but turn to the cases that indicate the nature and needs of the audience. For the analysis, we selected three groups of media activities: those that 1) focused on expanding the educational field for schoolchildren (the case ' 75 Years of the Great Victory'), 2) offered new forms of family leisure (the case 'Then an Inventor Appeared...') and 3) created new professional activity opportunities for teachers (the case 'Urals during the Great Patriotic War': scientific and methodological work in the context of digitalisation').

\section{Case ' 75 years of the Great Victory'}

2020 was declared the Year of Memory and Glory and marked by the anniversary of the Victory in the Great Patriotic War. If in the pre-COVID-19 era teachers built their work with schoolchildren by offering the traditional 
range of activities, such as conducting lessons of courage, visiting memorable places associated with heroic events of the war, meeting veterans, participating in military sports games and parades, then in the new context, there is a need to search for forms and means adequate to the situation.

Russian education found itself in a difficult situation, though, and like everything else in the world it was necessary to simultaneously establish the educational process in a distance format and continue to solve the problems of education. Let us leave aside the actual educational component of distance learning and turn to media activities, which at this time became decisive in the educational work. They can be provisionally divided into informational and educational, intellectual and creative media activities.

Information and outreach media activities include a variety of activities aimed at enhancing cognitive activity (lectures, conversations, round tables, viewing certain thematically collected media content) and causing an emotional response (watching performances, concerts, films, visiting virtual museums etc.).

Creative media activities include participation in various competitions (drawing contests, photo contests, literary or music contests), challenges (the genre of online videos in which a person performs a task on a video camera and posts it on the Web, and then offers to repeat this task to an acquaintance or unlimited circle of users), flash mobs (actions in which a large group of people simultaneously perform pre-determined actions), battles (competitions in which participants demonstrate their skills and/or achievements, and the Internet public votes for the creative product they like).

Intelligent media activities have an intermediate place between informational and outreach media activities and creative ones. Many of them involve a research component and, as an option, participation in individual or group project activities. Others are focused on game formats, such as quizzes and/ or express polls which are so popular on social networks.

The described media activities do not represent anything fundamentally new; rather, it is the adaptation of known forms to the needs of the modern technological stage of development. Information and outreach media activities normally involve a fairly wide audience and may not be oriented directly towards adolescents. Another thing is that teachers and parents focus on certain events and invite children and youth to join them.

For example, the topic of moral choice and the meaning of heroism were brought up to date when watching films about the war. Many teachers 
recommended to children and adolescents to watch feature films or documentaries, performances about the war presented on the Culture of the Russian Federation portal; then, if possible, invited them to a joint discussion of what they saw online. The range of films that were offered for viewing was quite wide; in general, those were classical films of the Soviet era (from The Ballad of a Soldier and The Cranes Are Flying to The Dawns Here Are Quiet... and The Fate of a Man). Discussing film production is a traditional activity for teachers and educators. Schoolchildren were invited to participate in the discussions of military-patriotic films made during the Soviet period or recently. Therefore, the transition to the remote format was reflected more in the form of discussion, such as online conferences, rather than on the nature of the activity. Interestingly, the discussion in the online conference mode began to engage not only the young audience but also their parents. A film, play or book about the war became the subject of conversation in the family circle, filling informal communication with some additional content.

During the lockdown period, virtual exhibitions became popular. For museums, exhibition or library and information centres, virtual excursions have become a form of drawing viewers'/readers' attention to active pastime. For example, specialists of the City Centre for the Protection of Monuments and the State Archives of the Sverdlovsk Region prepared the virtual exhibition Victory Was Forged Here dedicated to the fate of buildings and monuments of Ekaterinburg-Sverdlovsk during the war (the site http://победа. екатеринбург.рф).

Intellectual efforts, that encourage the cognitive activity of schoolchildren, were previously in demand when referring to historical materials, such as documents, personal stories, diaries and memoirs depicting the events of the Great Patriotic War. Quizzes to check the knowledge of events of the history of the war have become a popular form of intellectual leisure. Online games, in which participants have to answer questions about great battles, heroes or awards, were spread on social networks and attracted students. Internet communications, that erase territorial boundaries, turned out to be in demand and enabled residents of various regions to participate in various activities. Interestingly, along with cultural or educational institutions, schoolchildren themselves began to create such quizzes by posting them on social networks for their friends and subscribers. It seems to us that this format will turn out to be promising in the case of 'returning' offline as one of the forms of informal education to kindle interest in history. 
Educational and research projects of a historical orientation have long and firmly been growing into a habit of education. During the transition to the remote mode, the project activities acquired a fresh impetus and provided the basis for participation in various intellectual events, e.g. research competitions or the preparation of materials for the Memory Road gallery. Addressing the memory of your family, talking with the older generation, searching for photographs and letters from the front in home archives have combined the traditional project work, which is mandatory in school, and informal education, focused more on an emotional attitude to the historical past, and, as a result, encouraging research activities. At the same time, the presentation of the work outcomes in the form of a complex text combining photographs of the war years, pages from letters from the front, a story about the fate of a relative, became a new form of creativity via the media environment.

The number of creative contests held during the lockdown period is incalculable largely because they were organised in addition to federal or regional government bodies by a variety of institutions, such as libraries, creative unions, educational institutions or teacher communities. For example, as part of the Online Marathon \# 75 Words of Victory, an action was held in which famous actors, writers, cultural and sports figures, together with librarians from all over the country, read on the air lines from military correspondence, personal correspondence of soldiers, as well as excerpts from favourite books at the front and in the rear from the times of the Great Patriotic War. And schoolchildren from different parts of the country responded to the proposal to record a video with the reading of a memorable excerpt from a letter or a favourite book of the older generation of their family and post it to any social network with the hashtag \#75wordsofVictory.

In a large number of creative competitions, schoolchildren were invited to submit photographs, essays and video materials. The Ministry of Education of the Russian Federation invited children and adolescents to take part in the Russian patriotic action 'Letters of Victory' which united various events: competitions for knowledge of the state symbols of Russia, competitions of children's drawings 'My Great-Grandfather is a Winner!', videos 'I will tell you about the Victory' and graffiti on the topic of the Great Patriotic War', the poetry competition 'I Remember' and the essay competition 'Letter to the Front'. Thus, the already existing media activities were integrated into educational practices. 
Perhaps for the first time this year, large-scale campaigns began to be held, within the framework of which videos with the performance of songs or poems of the war years were posted on social networks. Initially, they were dedicated to exclusively the Victory but later they began to coincide with other public holidays. For the Day of Russia, the Russian Rhymes challenge was held and the participants of which recorded a video with the reading of poetry or excerpts from the works of Russian authors about the war; the Windows of Russia flashmob, during which a picture or congratulations on the holiday was glued to the window of an apartment or house, was organised; there was an action 'Bake a Pie and Say Thank You' the participants of which were invited to give a cake of their own to those whom one wanted to thank, and it ended with a competition for the best pie for which they had to vote for on social networks.

Memory Watch, the actions St. George Ribbon, Immortal Regiment or Candle of Memory were aimed at involving people in patriotic events and showed their effectiveness not only in the traditional face-to-face format, as they took place before the pandemic but also in the conditions of restrictions by providing an avenue for interaction between people. The joint performance of the famous song 'Victory Day' online has become a symbol of the unity of the inhabitants of the whole country regardless of age and place of residence.

An attempt to create communicative communities through arranging joint activities in an online format was made; for example, on specially created Internet sites, a variety of music festivals and gatherings were held on social networks to unite residents of various regions. The focus of such media campaigns is obvious, namely, to stimulate the creative activity of people and to ensure self-realisation in the context of restrictions associated with the high-alert mode.

For children and adolescents, participation in such events is also the promotion of a positive image of ' $T$.' Scientists have repeatedly noted that children and adolescents identify themselves with media characters with leadership skills. In part, participation in the proposed creative contests and promotions can be considered as prevention of the negative behaviour of children and adolescents in the information environment. If we remember that the cognitive interests of adolescents as indicators of self-identification are at the bottom of the rating of qualities that determine the image of ' $I$ ' [Koroleva, Bogdanovskaya, Lugovaya, 2014], then it can be said that there is the need to develop 
the media environment from the entertainment content itself prevailing now towards the educational, creative and intellectual contents contributing to the internal growth of children and adolescents.

We turn our attention to promising media practitioners, who have not yet become widely sought after but at the same time have a significant educational potential and may be in the area of interest of young people. That is the creation of blogs dedicated to the participation of children and adolescents in various events related to school life and extracurricular activities; the development of such an activity as travel journalism dedicated to travelling to the native land; creation of streaming programmes that discover in real time participation in patriotic actions or present their own experience in any activity; preparation of various research or creative projects with online presentation - in other words, the creation of a creative media environment in which young people of different ages can find an opportunity for realisation of their personal potential.

\section{Case 'Then an inventor appeared...'}

In educational practice, teachers strive to rely on the basic national values of Russian society (patriotism, social solidarity, citizenship, family, health, work and creativity, science, traditional religions of Russia, art, nature, humanity) and build their work by focusing on the development and education of a Russian citizen who accepts the fate of the Fatherland as his/her own, and is aware of responsibility for his/her country's present and future rooted in the spiritual and cultural traditions of the multinational people of Russia [Concept of Spiritual and Moral Development and Upbringing of the Personality of a Russian Citizen in General Education, 2009]. However, the ways and means of achieving this goal is still a debatable point. The integration of formal, non-formal and informal educational practices to ensure social and personal, intellectual, artistic and creative development through introducing pupils to the values of culture remains urgent. However, experience suggests that this ideal is still far from being achieved.

It is an indispensable element in the creation of cultural and civic identity to introduce pupils to the history and culture of the small homeland. For ten years, we have conducted informal expert interviews with teachers in Ekaterinburg and the Sverdlovsk region, the main focus of which was on the educational activities designed to acquire the social and cultural experiences by children and adolescents (mastering the system of traditional and current cultural standards and values transmitted, preserved and reproduced in so- 
cial and cultural practices). This experience is due to the self-determination of individuals, the acquisition and awareness of the meanings of their own activities (in educational, research, creative, volunteer and other activities); the developed self-awareness and reflection in the choice of social activity areas based on the accomplishment of personal aspirations and inclinations; by volitional effort when performing an assigned or independently chosen socially-oriented business; acceptance of responsibility to oneself, parents and others for the learning outcomes; independence in choosing the area of applying one's own forces; in the implementation of public-spirited and morally oriented actions.

Thus, the place of life, 'small homeland', becomes mainstream. Insight into the biographies of people who lived and live nearby, the study of the history and culture of the native land as an experience of mastering space in the transformative activities become steps towards the transformation of the territory where a person lives into his/her homeland, a place with which he/she feels a spiritual kinship. Consequently, the content aspect is of particular importance: knowledge about the region's history testifying to its uniqueness, images that represent the territory and forms of activity that reflect the ethos of the people living in the region. Shaping a unique image of the Sverdlovsk region, promotion of the region's industrial image through the creation and distribution of media, Internet, audio, video and printed products of a patriotic orientation have recently become a trend in the regional education and youth polices.

Today, the Sverdlovsk region as an industrially developed territory is faced with the challenge of increasing motivation of students of secondary schools to study subjects of the natural science cycle and the subsequent choice of technical professions and engineering specialties, which is enshrined in the conceptual provisions of the Ural Engineering School project for 2015-2034 (decree of the Sverdlovsk region's Governor dated 31 May 2016 No 307-UG). It will be more effective to fulfil such extensively formulated tasks if we rely on the region's historical experience and update it in modern conditions. To address the issue of schoolchildren's poor knowledge of the history of engineering and technical thought, the contribution to its development by the best representatives of the Urals science and technology fields, insufficient understanding of the relationship between the current state of the region's industry and the technical achievements of the past, the project 'Then an Inventor Appeared...' was proposed. 
The project objective was to create an electronic information resource 'Then an Inventor Appeared...' posted on the Web, the materials of which can be used to arrange for taskwork, extracurricular, out-of-school (cultural and leisure) activities in order to promote the technological solutions of the Urals. The social significance of the project, as conceived by the authors, consists in the development of schoolchildren's interest in the scientific and technical creativity on the basis of studying the activities of famous fellow countrymen and their discoveries which contributed to the development of the industrial potential of the Middle Urals; raising awareness and procedural competence among teachers in the history of science and technology; providing conditions for child-parent interaction via organising productive family leisure with the materials presented on the online information resource. In the long term, the project is aimed at strengthening regional identity and self-awareness as an important part of patriotic education based on introduction to the historical heritage.

This project has become unique in its own way: until that time, there was no such resource dedicated to the regional scientific and technical heritage. For the first time, an attempt was made to update the heritage of the Ural inventors by combining on one platform the historical and biographical information, features of engineering solutions, and to propose to conduct experiments or create models for the study of physical or chemical phenomena by schoolchildren that underlie the inventions of the Ural craftsmen. We consider the project as a model for both informal and non-formal education: the existing experience can be used to create individual and/or group projects for school-age children in the additional education system and when shaping work as part of a summer health campaign, or it can be used to arrange for family leisure.

The online resource 'Then an Inventor Appeared...' (http://izobr-ural.ru) is an attempt to combine education with entertainment (edutainment). The created product meets the infotainment and information combination requirements (in our case, about Ural inventors in the context of studying physics, chemistry and technology at school) with leisure practices (creating your own projects 'based on' inventions and presenting them on social networks). The content presented on the site (biographies of inventors and engineers; stories about their discoveries; referring to the materials studied in school courses; models proposed in the 'Studio' heading that you can make yourself; recommendations for parents on how to use the site materials 
to arrange for leisure together with your child) solves educational problems, entertains and, hopefully, educates by uniting children and parents.

The project was launched in the spring of 2020. Its approbation in the non-formal education (summer health camps) proved to be difficult due to the restrictions associated with the pandemic. According to the evaluations of parents who got acquainted with the electronic resource, the proposed experiments and models provided the basis for joint leisure, during which children became acquainted with physical phenomena that were studied remotely in the school physics course.

\section{Case 'Urals during the Great Patriotic War':}

\section{Scientific and Methodical Work in the Context of Digitalisation'}

Teaching activities are more focused on both formal and non-formal education. Educators, who are aware of professional deficiencies, turn to various courses, training, additional professional programmes to acquire the necessary skills and competencies in order to work with children and adolescents. In the situation of entirely switching to online education, short-term programmes and webinars aimed at mastering certain information and communication educational platforms, that provide work with children remotely, started to gain in popularity. In part, the features of additional education were taken over by social networks and teacher communities that have operated in the electronic environment and provided mutual teacher training.

In recent months, the situation has been complicated by the fact that many teachers had to not only master new learning formats for themselves and look for opportunities for the implementation of educational tasks but also select from the huge content on the Internet that would be more suitable for solving educational problems. In this context, traditional research and methodological products (books and scientific and methodological articles) gave way to electronic resources. During the COVID-19 pandemic, many publishing houses of research and methodological products began to actively distribute electronic copies of the published books in order to at least partially meet the emerging demand. Electronic libraries have also become more active in the selection and offer of methodological products. In fact, research and methodological book publishing has not undergone any serious transformations, except for the replacement of paper books by their electronic versions.

Recently, expanding the resource base of education, also by including previously unknown or little-known materials, has also become a trend. This is clearly seen by the example of historical and cultural studies many of which 
teachers were previously unaware of. The research papers by domestic and foreign scientists, presented via wider access on the Internet, have become more accessible and have been included in educational content for studying domestic history. However, it was often a problem to assess the quality of certain works associated with the explicit or latent bias of the authors.

Due to the pre-determined topic, we will again turn to the military example by relying on the regional presentation experience. In our opinion, an appeal to regional history in the context of a military theme should become a de-ideologised and de-mythologised space in which a young person truly encounters the history of the country like his/her own history. This is a unique opportunity for education to combine experience-emotional upheaval (emotional attitude to events of the past), experience-cognition (study of historical documents of eyewitness accounts of those events) and experience-action (participation in research, search, volunteer activities).

The recent romanticisation of war and many blockbusters that create the illusion of ease of victory, an emphasis on heroic events, that neutralise the understanding of everyday hard work both at the front and in the rear, all this creates additional difficulties for teachers and parents involved in educating the younger generation. Teachers are challenged to create a value-based attitude towards the history of their country through emotional experience (sympathy) by creating the foundation for civic and cultural identity.

The theme of the feat of the rear, the contribution of the Urals to the Victory in the Great Patriotic War is one of the most important in the shaping of the historical consciousness of young people. We have set the task of including materials related to wartime events in the actual space for modern schoolchildren to study. The task was designed to solve the publication of teaching materials for teachers, which are based on historical and cultural works published in recent decades. Addressing the theme of the Great Patriotic War in modern schools very rarely includes research conducted in the last two decades; teachers and methodologists rather turn to the works of historians of the Soviet era. At the same time, in the post-Soviet period in historical science, events were utterly reassessed. The discovery of many previously classified documents and their introduction into scientific circulation made a picture of the period 1941-1945 more opaque and more dramatic. If in previous years special emphasis was put the theatre of military activities and operations, in recent decades the emphasis has shifted towards studying living conditions in the rear, i. e. personal stories, individual and 
family experiences - all of this is now part of the educational field and requires additional reflection by teachers.

The generality of the historical memory represented in artifacts, texts, rituals and traditions as the embodied unity of historical fate, is used as a consolidating principle for social groups and societies. Consequently, understanding events, heroes or phenomena labelled in the collective memory as 'ours' becomes a condition for the formation of cultural identity, which, in turn, is a 'guideline to follow' for the education system, i. e. acquainting ourselves with historical collisions and shaping a positive (at the same time, not necessarily attractive but labelled as meaningful) image of the collective past.

Today, historical traditions are introduced by the efforts of teachers in both the lessons of social and humanitarian disciplines (history, literature, the foundations of religious cultures and secular ethics), and in extracurricular activities (museum excursions and tourist-local history workshops), and in educational work (organisation of memorial events). It is explored at two levels, the informational level (the knowledge about historical events, 'heroes' of the past, sites of battles etc.) and activity-event level (the development of research projects, creative activity or participation in memorial actions). An essential condition for introducing pupils to traditions is the emotional experience of the past (collective, joint $c o$-experience), which provides a live connection' with the present.

The tasks of methodological publications in the new conditions are 1) selection and the possibility of including materials devoted to life in the rear into educational practice; 2) identification of the potential of new information technologies in the creation of an wider representation of a given period; 3) creation of methodological comments that will help a teacher to use the presented materials in his/her work. In the context of the topic of our research, it should be noted that the appeal of teachers towards research and methodological products can be considered as an informal educational practice.

In creating the book 'From Rear to Front. 1941-1945', we tried to methodically present historical material for teachers in a small edition (the substantive part); to create a polyphonic space linking eyewitness accounts, historical documents and recent academic research (a space of dialogue with the historical time); to combine the non-linearity of presentation and the availability of audio and visual materials (creolised text); prepare methodological 'keys' for the lesson and extracurricular activities (methodical 
commentary). As a technological tool, we used QR codes (an abbreviation for quick response) - two-dimensional barcodes that can be used to access information on mobile devices.

Today, the QR-coding technology is considered by researchers as an innovative method of presenting information, when the material of various volumes and content can be presented in a collapsed form - from a business card of an enterprise created for advertising purposes to personal data of a person; from the information about an artifact in a museum or a tourist site to the design of an architectural space as in the information project of the Skolkovo innovation city presented at the Venice Biennale and repeated in Zaryadye. Access to information is granted in 'reading' by a smartphone, tablet or laptop with a video camera by a preinstalled QR code scanning programme. Recently, this informational presentation method has become widespread in education. It is used to motivate students to read educational or fictional literature (the QR code is placed on the bookshelves of school libraries); they are attracted to participate in various quests (the QR code accompanies the 'route sheet' with which tasks need to be accomplished), expand the information field of academic subjects (the QR-code gives access to accompanying materials, such as diagrams, charts, graphs, tables, pictures, audio files), encode the information about educational and scientific events. As a rule, QR codes in books contain the information about the publisher, the business card of the publication.

As rightly noted by S. A. Glazkova, this technology is used as a new communicative practice, i.e. mobile communication which has gained widespread use in the field of marketing, interpersonal contacts, symbolic/ritual acts and contemporary art, the subject of which is the communicative act per se [Glazkova, 2012, 65]. Especially for young people, such significant features of this type of communication become attractive as new features for obtaining information; availability and at the same time selectivity of obtaining information associated with the need to use additional software and certain models of a mobile communication device; personality-oriented (personified) information.

We have considered the use of QR codes within the text of a textbook for teachers in the context of the creation of new communicative trends, i.e. the development of activity in shaping one's own position to the presented material, the inclusion of layers of different times in a single educational field, 
the creation of conditions for the formation of a network community in respect of the problem under study (going beyond the edition's boundaries).

Here are some examples. The topic dedicated to the peculiarities of the evacuation of industrial enterprises to the Urals is provided with several QR codes. One refers to the site 'Documents of the Soviet Era' (Project of the Federal Archival Agency), the link allows a teacher in his/her work to involve various wartime documents for analysis with students by expanding the source base of the topic under research. Resorting to regional sources is provided by the QR-code of the site 'Tagil of the Wartime' which includes the systematised information based on the materials of the Tagilskiy Rabochy newspaper. The emotional background is created by a QR-code that 'hides' the documentary film 'Labour Feat of Nizhny Tagil' (2020) created on the basis of the film 'City N'. (1944). The QR code, in which the 'Information about the Hospitals Located in Sverdlovsk during the Great Patriotic War of 1941-1945' is encrypted, provides for the future project activities of students, since many of the hospitals were located in schools, as evidenced in school museums... The materials pointed to by QR codes are freely available information on the Internet.

By solving the problem of the emotional involvement of modern schoolchildren in the events of the Great Patriotic War, we tried to prepare some audio and visual materials for a teacher including feature films and documentaries, the viewing of which can be recommended at home, or in fragments - during lessons or as extracurricular activities. This is also a reference to documentary films by contemporary authors, for example, The Evacuation Novel dedicated to the evacuation of the Leningrad Opera and Ballet Theatre named after Kirov (Mariinsky Theatre) to Perm (scriptwriter and director B. Karadzhev; the film studio 'New Course', 2011), or 'Rear of Art' (script: A. Kondrashova; Production of the UOTK 'Ermak', 2015), and films shot during the war and became significant for that time, the film essay 'City N.' (director: Vl. Boykov; production of the Sverdlovsk newsreel studio, 1944), the documentary 'Ural Forges Victory' (director: Vladimir Boykov; production by the Sverdlovsk and Kuibyshev newsreel studios, 1943), the feature film 'Silva' (director: A. Ivanovsky; production of the Sverdlovsk film studio, 1944).

Since the potential audience of our publication is represented by teachers of various subject areas, the task was to expand the possibilities of addressing the region's culture during the war years: for music teachers, through the inclusion of audio material (QR codes: 'The Song 'The Urals 
are Beating Greatly', music by T. Khrennikov, lyrics by A. Barto; performed by the choir of the music school under the direction of A. Kuznetsova, 2013 or 'Article by Musicologist M. Cheremukhin about opera by V. Trambitsky 'The Thunderstorm' from the magazine 'Soviet Music', 1940); for teachers of the world's art culture - the documentary 'Hermitage. Chronicle of Feat' (script: Yu. Osipov; director: E. Sulla; production: STS Studio, 2004). To arrange for project activities of the social and cultural nature, a link to a film about workers and children of the rear, was provided, prepared by students of school No 1273 (Moscow, 2016).

The QR code 'Great Victory Virtual Guide dedicated to the Year of Memory and Glory - 2020', which addresses the list of resources, has become a summary material that methodically represents various materials posted on the Internet and dedicated to the Victory in the Great Patriotic War collected by the library staff of the information centre of the Financial University under the Russian Federation Government.

For information not uniform in quality in a published product, it was necessary to prepare for the material presentation. By using traditional typography methods (with different fonts for different quality information, headings and logos, headings of several levels, background 'substrates' for short titles etc.), we tried to create a visually complex whole reflecting the polyphonic structure of the text.

The inclusion of QR codes has defined a special type of creolised text based on the combination of verbal text with elements of virtual reality. The creolised text of this type is more typical of advertising media products than research and methodological publications. However, in our case, it was justified as a new communication format providing additional expressiveness to the statement and 'reflecting a heterogeneous, polycentric and non-linear perception of the world around' [Tumakova, 2016, 49].

In our case, we broadly interpret the 'creolized text' concept as a set of information sources that meet the task of free choice of educational material and include, within a single topic, printed text, visual and audiovisual materials. Consequently, we consider our teaching and learning aids as a creolised text on the topic 'The Urals during the Great Patriotic War', and methodological comments as the 'keys' to its use. Algorithms for working with a written, visual and audiovisual source, forms and methods of organising task-work, extracurricular and extracurricular activities, the creation of museum information projects with digital technologies become such 'keys'. 
The nature of the publication is scientific and methodical and it involved the preparation of a more or less detailed methodological commentary on the information offered. Proceeding from the principle that a modern teacher is distinguished by a creative and critical attitude to any proposed recommendations and descriptions of educational practices, reflexivity and reasonable doubt about the appropriateness of repetition and reproducibility of certain techniques, methods and technologies in a particular school, we decided to designate individual educational initiatives used in Russian education and aimed at the patriotic education of young citizens.

Since the book was released by the printing house at the very beginning of the restrictive measures associated with the high-alert mode during the pandemic, the paper-based publication was not available to teachers. The electronic version presented in the open access for reading, as the readers noted in the reviews, was especially interesting in terms of its technological concept: the ability to simultaneously use a computer and a mobile device turned out to be a new and interesting experience that will come in handy in preparing lessons with schoolchildren.

\section{Conclusions}

As a result of the conducted research, it can be stated that the described informal educational media practices, despite their specific content (Russian patriotic discourse), can be considered as versatile. Thus, the informational, educational, intellectual and creative media activities presented in the first case can be reproduced with any other, not necessarily historical, material. The practice of creating and using an electronic resource (the second case) sets the vector for addressing the possibilities of natural science and technical education by offering it as a material for the joint creativity of children and parents. Supplemented by the forms and methods of working in the media environment described in the first case, it acquires a new quality, namely it becomes a part of the educational content, for both formal and non-formal educational segments. The use of new technological solutions in a research and methodological publication (the third case) enriches the package of teaching tools that can be updated in professional activities.

We examined three cases that represent informal educational media practices in modern Russia. To summarise, it should be noted that in the context of the restrictions associated with the COVID-19 pandemic, the role of informal education is increasing by providing the needs for self-education 
and leisure activities. It is becoming obvious that media practitioners, who were previously on the periphery of educational activities, have demonstrated their potential in present-day developments. For the Russian education system, the experience gained is valuable in that new teaching and upbringing formats have been tested, the use of which can expand the range of teaching tools in both formal and non-formal education.

\section{Acknowledgment(s)}

The author expresses gratitude to the Ministry of Education and Youth Policy of the Sverdlovsk Region for supporting the projects 'From Rear to Front': Teaching and Learning Aids' (Agreement No 1572), 'Electronic Information Resource 'Then an Inventor Appeared...' (Agreement No 1572), 'The Culture of the Urals: Development of Intercultural and Interethnic Integration' (Agreement No 1345).

\section{References:}

1. N. Negroponte. Being Digital. Vintage Books, New York (1995).

2. S. W. Elliott. Computers and the Future of Skill Demand. OECD Publishing, Paris (2017) http://www.oecd.org/edu/computers-and-the-future-of-skill-demand-9789264284395-en.htm (Accessed 5 August 2020).

3. J. Devine. Personalized Learning Together. Open education 2030. Jrc-Ipts Call for Vision Papers. Part II: School Education. (2014) http://blogs.ec.europa.eu/openeducation2030/files/2013/05/Devine-OE-SE-2030-fin.pdf (Accessed 10 August 2020).

4. J. R. Valadez, R.P. Durán. Redefining the digital divide: Beyond access to computers and the Internet. The High School Journal, Vol. 90 (3) (2007), pp.31-44.

5. S. T. Kerr. Why we all want it to work: Towards a culturally based model for technology and educational change. British Journal of Educational Technology, Vol. 36, No. 6 (2005), pp.1005-3016.

6. A. U. Uvarov, S. Van, T. Kan et al. Problemy i perspektivy tsifrovoy transformatsii obrazovaniya v Rossii i Kitaye [Problems and prospects of digital transformation of education in Russia and China]. II Rossiysko-kitayskaya konferentsiya issledovateley obrazovaniya "Tsifrovaya transformatsiya obrazovaniya i iskusstvennyy intellekt" [II Russian-Chinese conference of educational researchers "Digital transformation of education and artificial intelligence"]. Moscow, Russia, September 26-27, 2019. Izd. dom Vysshey shkoly ekonomiki, Moscow (2019)

7. Trudnosti i perspektivy tsifrovoy transformatsii obrazovaniya [Difficulties and prospects of digital transformation of education]. Edited by A. U. Uvaro- 
va, I. D. Frumina. Izdatel'skiy dom Vysshey shkoly ekonomiki, Moscow (2019), 10.17323/978-5-7598-1990-5

8. K. Shvab. Chetvertaya promyshlennaya revolyutsiya [The fourth industrial revolution]. Eksmo, Moscow (2016).

9. Novaya tekhnologicheskaya revolyutsiya: vyzovy i vozmozhnosti dlya Rossii: ekspertno-analiticheskiy doklad [New technological revolution: challenges and opportunities for Russia: expert-analytical report]. Edited by V.N. Knyaginina. Tsentr strategicheskikh razrabotok [Center for Strategic Research], Moscow (2017).

10. I. L. Goldman. Iskusstvovedchesko-kul'turologicheskiye oriyentiry obrazovatel'noy deyatel'nosti v sfere mediakommunikatsiy [Art history and cultural guidelines of educational activities in the field of media communications]. Znak: problemnoye pole mediaobrazovaniya [Sign: the problem field of media education], № 1 (31) (2019), pp. 141-147.

11. I. V. Chelysheva, V.S. Shapovalova, E. V. Muryukina. Teoriya i metodika razvitiya sotsial'noy aktivnosti shkol'nikov s ispol'zovaniyem elementov mediaobrazovaniya: monografiya [Theory and methodology for the development of social activity of schoolchildren using the elements of media education: monography]. Direkt-media, Moscow-Berlin (2019).

12. T. V. Korniyenko, A. A. Potapov, T. N. Petrova. Profil'noye obucheniye shkol'nikov sredstvami mediaobrazovaniya: monografiya [Profile training of schoolchildren by means of media education: monography]. Naukoyemkiye tekhnologii [Science-intensive technologies], Saint Petersburg (2020).

13. A. V. Fedorov. Mediaobrazovaniye: istoriya i teoriya [Media Education: History and Theory]. MOO “Informatsiya dlya vsekh", Moscow (2015).

14. I. Y. Murzina. Sotsiokul'turnaya sostavlyayushchaya aktual'nykh obrazovatel'nykh praktik (Ural'skiy keys) [Socio-cultural component of current educational practices (Ural case)]. Pedagogicheskiy zhurnal Bashkortostana [Pedagogical journal of Bashkortostan], № 4 (83) (2019), pp. 79-83.

15. N. V. Chekalova, O. V. Roytblat, N. N. Surtayeva. Otnosheniye k protsessu integratsii formal'nogo, neformal'nogo i informal'nogo obrazovaniya vzroslykh [Attitude towards the integration process of formal, non-formal and informal adult education]. Letters to the Issue. Offline. March. (2012), http://www.emissia.org/ offline/2012/1755.htm (Accessed 15 October 2018)

16. V.P. Kolomiyets. Mediasreda i mediapotrebleniye v sovremennom rossiyskom obshchestve [Media environment and media consumption in modern Russian society]. Sotsiologicheskiye issledovaniya [Sociological research], № 1 (2010), pp. 61-72. 
17. N. A. Simbirtseva. Mediaaktivnost' kak lichnostnoye kachestvo cheloveka postindustrial'noy kul'tury: na puti resheniya problem [Media activity as a personal quality of a person of post-industrial culture: on the way to solving the problem]. Chelovek i kul'tura [Man and Culture], № 4 (2016), pp. 1-8, 10.7256/24098744.2016.4.19826

18. N. N. Koroleva, I. M. Bogdanovskaya, V.F. Lugovaya. Vozdeystviye sovremennoy informatsionnoy i mediasredy na "obraz Ia" podrostkov [The impact of the modern information and media environment on the "self image" of adolescents]. UNIVERSUM: Bulletin of the Herzen University, № 2(2014), pp. 87-94.

19. Kontseptsiya dukhovno-nravstvennogo razvitiya i vospitaniya lichnosti grazhdanina Rossii v sfere obshchego obrazovaniya: proyekt [The concept of spiritual and moral development and upbringing of the personality of a citizen of Russia in the field of general education: project]. By A. I. Danilyuk, A. M. Kondakov, V. A. Tishkov. Russian Academy of Education. Prosveshcheniye, Moscow (2009).

20. S. A. Glazkova. Tekhnologiya QR-kodov v mobil'nom kommunikativnom prostranstve [QR-codes technology in the mobile communication space]. Gramota: Istoricheskiye, filosofskiye, politicheskiye i yuridicheskiye nauki, kul'turologiya i iskusstvovedeniye. Voprosy teorii i praktiki [Diploma: Historical, philosophical, political and legal sciences, cultural studies and art history. Questions of theory and practice], № 11 (25) (2012), Part. II, pp. 61-66.

21. E. V. Tumakova. Kreolizovannyy tekst v khudozhestvennom i mediynom diskurse [Creolized text in fiction and media discourse]. Mir russkogo slova [The world of the Russian word], № 2 (2016), pp. 43-49. 